\title{
ANNUAL PSYCHOLOGICAL SCREENING IN YOUTH AND YOUNG ADULTS WITH TYPE 1 DIABETES LETNO PRESEJALNO PSIHOLOŠKO TESTIRANJE PRI MLADOSTNIKIH IN MLADIH ODRASLIH S SLADKORNO BOLEZNIJO TIPA 1
}

\author{
Simona KLEMENČIČ ${ }^{1, *}$, Maartje de WIT ${ }^{2}$, Miha RUTAR ${ }^{1}$, Tadej BATTELINO ${ }^{1,3}$, Nataša BRATINA ${ }^{1}$ \\ ${ }^{1}$ University Medical Centre Ljubljana, University Children's Hospital, Department of Pediatric Endocrinology, \\ Diabetes and Metabolic Diseases, Bohoriceva 20, 1000 Ljubljana, Slovenia \\ 2Diabetes Psychology Research Group, Department of Medical Psychology, EMGO Institute for Health and Care Research, \\ VU University Medical Center, Amsterdam, The Netherlands \\ ${ }^{3}$ University of Ljubljana, Faculty of Medicine, Vrazov trg 2, 1000 Ljubljana, Slovenia
}

Received/Prispelo: Oct 31, 2014

Accepted/Sprejeto: Jan 14, 2015

Original scientific article/lzvirni znanstveni članek

\section{ABSTRACT}

Keywords:

depression, diabetes distress, fear of hypoglycemia, family support, glycemic control

\section{IZVLEČEK}

\section{Ključne besede:} depresija, depresivne motnje, presejalno psihološko testiranje, hipoglikemija, podpora družine, sladkorna bolezen tipa 1 , mladostnik
Aim. Youth and young adults with type 1 diabetes are at a great risk for developing depression and diabetes specific distress, therefore, systematic psychological screening is recommended. Routine psychological screening was implemented in Slovene diabetes clinic for children, adolescents and young adults in 2012. One-year results are presented.

Methods. Adolescents and young adults $(N=159$, aged $11-25$ years), attending the obligatory yearly educational outpatient visit at University Children's Hospital, Ljubljana, Slovenia, were examined using questionnaires measuring depression (depression scale from Slovene version of Trauma Symptom Checklist for Children) and diabetes distress (Diabetes Distress Screening Scale). Six additional items were included to assess the fear of hypoglycemia and family support. Socio-demographic and diabetes-related data were collected. Questionnaires were analyzed by a psychologist, and the patients that scored above cut-off point were invited to an individual psychological assessment.

Results. Of the sample, $1.3 \%$ reached the threshold for elevated depressive symptoms, and $32.7 \%$ reported significant diabetes distress. The need for psychological support from a specialist was expressed by 5.0 $\%$. There were statistically significant associations between all psychological variables; moreover, better glycemic control was associated with lower diabetes distress and better family support. Nine patients (5.7 $\%)$ started with psychological treatment according to the referrals after screening.

Conclusions. The results after one year of psychological screening in Slovene type 1 diabetes population displayed small rates of depression and a large proportion of diabetes distress. Only a small percentage of patients attended the offered individual psychological assessment.

Namen raziskave. Pri mladih s sladkorno boleznijo tipa 1 je prisotno večje tveganje za razvoj depresivne motnje, pogosto pa ti bolniki poročajo tudi o obremenjenosti s sladkorno boleznijo. Zato se priporoča psihološko presejalno testiranje. V letu 2012 smo presejalno testiranje za mladostnike in mlade odrasle uvedli tudi $v$ Sloveniji ter prve rezultate predstavili $\vee$ tej raziskavi.

Metode. Rednega letnega edukacijskega pregleda na Kliničnem oddelku za endokrinologijo, diabetes in bolezni presnove Pediatrične klinike se je udeležilo 175 mladostnikov in mladih odraslih, starih od 11 do 25 let. Od teh jih je 159 rešilo presejalni vprašalnik, ki je ocenjeval depresivne simptome (lestvica depresije iz vprašalnika o travmatiziranosti otrok in mladostnikov) in obremenjenost s sladkorno boleznijo (presejalna lestvica za oceno obremenjenosti s sladkorno boleznijo). Dodanih je bilo šest postavk za oceno strahu pred hipoglikemijo in podporo družine. Zbrali smo podatke o sladkorni bolezni in sociodemografskem ozadju. Psiholog je pregledal vprašalnike in podal kratko mnenje, mladostnike in odrasle, ki so presegli kritično število točk, pa smo povabili na posvet in dodatno obravnavo k psihologu.

Rezultati. Rezultate, ki pomenijo povečano tveganje za depresijo, je doseglo 1,3 \% udeležencev, 32,7 \% udeležencev pa je poročalo o pomembni obremenjenosti s sladkorno boleznijo. Željo po psihološki obravnavi je izrazilo 5 \% preiskovanih. Prisotna je bila statistično pomembna povezanost med vsemi psihološkimi parametri. Dobra presnovna urejenost je bila povezana z manjšo obremenjenostjo s sladkorno boleznijo in boljšo podporo družine. Devet $(5,7 \%)$ mladih je po presejalnem psihološkem testiranju pričelo obravnavo pri psihologu.

Zaključki. Prvo leto presejalnega psihološkega testiranja mladih s sladkorno boleznijo tipa 1 je pokazalo nizek delež udeležencev z depresivnimi simptomi in visok delež pacientov, ki so izrazito obremenjeni s sladkorno boleznijo. Le majhen delež udeležencev se je odzval na povabilo na obravnavo pri psihologu in začel obravnavo.

*Corresponding author: Tel: +386 152292 32; E-mail: simona.klemencic@kclj.si 


\section{INTRODUCTION}

Youth and young adults with type 1 diabetes (T1DM) are at an increased risk for the development of depression and other psychiatric disorders (1). Moreover, distress, associated with the chronic illness, is an additional burden to patients, especially for adolescents who already have stronger emotions, poorer self-control, self-esteem problems and worse glycemic control (2-4). Especially adolescents who have more peer-conflicts, more negative diabetes-related emotions, less parental involvement in diabetes care and are less psychologically mature are at the risk for declines in the glycemic control (5-7). Early recognition of emotional problems and timely interventions are of major importance in order to help children and youth at risk.

Depression is one of the most commonly occurring comorbid conditions among youth with diabetes (1). The estimated prevalence of depression among children and adolescents with T1DM varies from $8 \%$ to $15.2 \%(8-11)$, depending on the population studied and methodology used. Most of the studies found that the level of depressive symptoms was higher in adolescents with diabetes than in the general population, or when compared to healthy controls (9-12).

Comorbidity of T1DM and depression or diabetes-specific distress can lead to worse diabetes self-management, especially less frequent blood glucose monitoring (BGM), poorer glycemic control, and to an earlier onset of diabetes complications (8, 9, 13-17). Moreover, higher anxiety predicted higher glycosylated hemoglobin A1c (HbA1c) values in the future (17). Similarly, higher diabetesspecific distress reported by adolescents was associated with poorer glycemic control, depression symptoms and lower quality of life (2).

Fear of hypoglycemia (FoH) increases psychological distress associated with diabetes, and also has a negative impact on the diabetes management and glycemic control $(18,19)$. Even though FoH is not directly associated with glycemic control, the elevated fear may motivate some patients to take counter actions to prevent hypoglycemia at the expense of experiencing unhealthy high glucose levels $(18,20-22)$.

Family support is another factor that contributes to youth wellbeing and treatment compliance (23). Parental involvement in diabetes management supports more frequent BGM (24). Shared responsibility for diabetes management is associated with a better psychological health, good self-care behavior, and a better glycemic control (25), while perceived 'over-involvement' of parents is related to poorer glycemic control (26). Family communication and conflict resolution skills have also been found as strong predictors of the diabetes outcome variables (27). Moreover, frequent conflicts between the child and his parents have been associated with poorer adherence and glycemic control $(28,29)$, and, nonetheless, with the child's depression (9).

American Association for Diabetes (ADA) and International Society for Pediatric and Adolescent Diabetes (ISPAD) recommend routine annual screening for depression of all young patients with T1DM above the age of ten years $(30,31)$. Additionally, youth with difficulties achieving treatment goals, or with recurrent diabetes ketoacidosis, should be screened on psychiatric disorders, psychosocial functioning, especially on depression and family coping. Patients with positive screening should be referred promptly for treatment (30). No special instruments or screening tools are recommended by the mentioned guidelines.

Although psychological screening is recommended, it is rarely formally conducted due to the barriers of its implementation. Butwitcka and her colleagues compared the diagnostic accuracy and time expenditure models of screening models for mood disorders among children with T1DM (32). The results of this study showed that the use of $\mathrm{HbA1C}$ levels as a first screener (with threshold at 8.7\%), followed by Children's Depression Rating Scale, was more time-efficient and accurate procedure to screen for mental disorders than screening with HbA1c levels, followed by the Children Depression Inventory (CDI) or CDI alone. Corathers and her team screened adolescents with T1DM with the electronic version of CDI (16). Elevated CDI scores $(\geq 16)$ were found in $8 \%$ of sample and suicidal ideation was reported by $7 \%$ of the sample. For those patients, a referral to a social worker was arranged on the same day of screening and outpatient psychological service on the next day. Both patients and staff reported acceptance of screening, while authors evaluated it challenging, but feasible.

The presented program therefore aimed to screen for patients with emotional problems, namely, depression, diabetes distress, $\mathrm{FoH}$ and a lack of family support, and to provide them fast psychological intervention. Preliminary results after one year of screening are presented.

\section{METHODS}

\subsection{Subjects}

University Children's hospital Ljubljana is the only center for childhood diabetes in Slovenia. Currently, 650 children, adolescents and students up to the age of 25 years are regularly visiting the outpatient clinic for diabetes.

Adolescents and young adults with T1DM in the age range between 11 and 25 , attending the yearly regular educational outpatient visit at the Department of Pediatric Endocrinology, Diabetes and Metabolism, University Children's Hospital, Slovenia, were enrolled in the study 
between March 2012 and June 2013. The inclusion criteria were the presence of T1DM for at least two years, and a minimum age of 11 . The participation was voluntary; of the 175 invited patients, 159 answered the Questionnaire for psychological screening (the response rate was 90.8 $\%)$. One hundred and forty-one (88.7\%) participants used continuous subcutaneous insulin infusion (insulin pump), and the rest $(18,11.3 \%)$ multiple daily injections.

All patients signed an informed consent prior to enrolment. The study protocol was approved by the National Medical Ethics Committee (Approval No. 76/03/13).

\subsection{Measures}

\subsubsection{Questionnaire for Psychological Screening}

A screening questionnaire was developed to identify the patients at risk and in need of psychological support. Items measuring depressive symptoms, diabetes distress, FoH and family support were included. Each domain was evaluated separately. The patients were also asked about the school performance (possible answers: 1 - very poor, 2 - poor, 3 - average, 4 - good, 5 - very good). Moreover, they answered the question if they would like to have psychological support from an expert (yes/no).

\subsubsection{Depressive Symptoms}

The depression scale from the adapted Slovenian version of Trauma Symptom Checklist for Children (TSCC) was used to assess depressive symptoms (33). Normative data for Slovene population between age of 10 and 18 are provided. The depression scale contains 9 items (with answer options on 4 point Likert scale: 0 - never, 1 sometimes, 2 - often, 3 - always) and has a high internal consistency (Cronbach's alfa $=0.85$ in healthy population and 0.89 in a clinical sample). There are high correlations between depression scale of TSCC and scores on CDI $(r=0.68-0.73)(33,34)$ and between TSCC depression and Beck Depression Inventory $(r=0.81)$ (35). Cut-off point for elevated depressive symptoms was set at scores that correspond to $T$-scores at and above 65 (1.5 standard deviations above the mean), that are generally considered clinically significant.

\subsubsection{Diabetes Distress}

Diabetes-specific distress was evaluated using The Diabetes Distress Screening Scale (DDS2) (36). DDS2 includes two items from the Diabetes Distress Scale - DDS17, and showed a high level of accuracy $(96.7 \%)$, good sensitivity (95\%), good specificity (85\%) and $3.3 \%$ of false-positive results when assessing diabetes-specific distress. DDS2 uses a 6 point Likert scale with each item scored from 1 (no distress) to 6 (serious distress), concerning distress experienced over the last month. Those patients whose average of the 2 screening items was $\geq 3$, were included in further procedures.

\subsubsection{Fear of Hypoglycemia}

FoH was assessed with three questions regarding having worries of not recognizing hypoglycemia (1), not having supplies to treat blood sugars in case of hypoglycemia (2), and fear that no one could help when having hypoglycemia (3). Patients answered them on 5 point Likert scale from 0 (never) to 4 (always). Those patients who scored 3 (often) or 4 (always) on any of the three items were included in further procedures.

\subsubsection{Family Support}

Family support, family conflicts and appropriate involvements of parents in diabetes, were assessed using the following three statements: There are a lot of conflicts between me and my parents due to diabetes. (1), My parents are overprotective regarding diabetes. (2), and My family does not give me enough support with my diabetes self-management. (3). Patients answered the items on 5 point Likert scale from 0 (never) to 4 (always). Patients with scores 3 (often) or 4 (always) on any of the three items, were included in further procedures.

\subsubsection{Adherence to the Treatment}

An average number of BGM per day over past three or four weeks was downloaded from insulin pumps to assess one of the components of patients' adherence to the diabetes regiment. Next to the pump downloads, diabetes diaries were checked also. For patients that used multiple daily injections insulin therapy, the average number of BGM per day was assessed from their diabetes diaries; moreover, the data from glucometers was downloaded for verification.

\subsubsection{Glycemic Control}

Glycemic control was assessed using $\mathrm{HbA1c}$, measured with the DCA 2000 + analyzer (Bayer Diagnostics, Tarrytown, NY). The measures were obtained at outpatient visits.

\subsection{Procedures}

The patients attending regular yearly educational visits were invited to complete the Questionnaire for psychological screening. Health and specific diabetesrelated variables (such as HbA1c, type of diabetes treatment, age of diabetes onset, insulin delivery method) were collected. A psychologist analyzed the questionnaires and wrote a short report for the patient, parents and diabetologist. The patients that scored above the cut-off point for depressive symptoms, or expressed any need for psychological support, were invited to a scheduled psychological treatment for further diagnostic procedures and cognitive behavior therapy. Parents were 
also invited to this session if the patient was below the age of 18 years. The patients that reached the cutoff scores on any other of the three domains (diabetes distress, FoH or family support), were invited to call (or make an e-mail contact) and schedule their appointment with a psychologist as well.

\subsection{Statistical Analysis}

Analyses included descriptive statistics to characterize the sample, and the $t$-test or Mann-Whitney test for assessing the between-group differences. Spearman's and Pearson's coefficients of correlation were used to evaluate the association between psychological, sociodemographics and health-related variables. The model of multivariate linear regression analysis was built to evaluate the predictors of diabetes distress.

The level of significance was set at 0.05. Statistical analyses were performed using the statistical software package PASW $®$ Statistics 18.0.0 (37) and G*Power 3.1 for statistical power analyses (38).

\section{RESULTS}

Baseline characteristic and diabetes-related variables are summarized in Table 1. Average test scores of psychological domains on the Questionnaire for psychological screening are presented in Table 2. Only two patients reported elevated depressive symptoms, but nearly one third (32.7 $\%)$ of the patients reported significant diabetes distress.

The need for a psychological support from a mental health specialist was expressed by eight patients $(5.0 \%)$, whereas four patients $(2.5 \%)$ did not answer this question. The patients that expressed the need for support reported higher depressive symptoms $(M-W=248, p=0.005)$ and a higher diabetes distress $(M-W=244.5, p=0.005)$. Most of them were girls (seven vs. one boy).

Table 1. Baseline (socio-demographic and health-related) characteristics of study participants $(N=159)$.

\begin{tabular}{|c|c|c|c|}
\hline Variable & $N(\%)$ & Mean $\pm S D$ & Min - Max \\
\hline Age (years) & & $17.97 \pm 3.30$ & $11-25$ \\
\hline Age of diabetes onset (years) & & $8.64 \pm 3.93$ & $1-19$ \\
\hline Female sex & $67(42.1)$ & & \\
\hline School performance ${ }^{*}(N=156)$ & & $3.87 \pm 0.91$ & $1-5$ \\
\hline HbA1c (\%) & & $8.02 \pm 1.04$ & $5.9-11.9$ \\
\hline BGM (measures per day) & & $5.00 \pm 1.86$ & $0.4-10.5$ \\
\hline \multicolumn{4}{|l|}{ Diabetes treatment regimen } \\
\hline Continuous subcutaneous insulin infusion & $141(88.7)$ & & \\
\hline Multiple daily injection & $18(11.3)$ & & \\
\hline
\end{tabular}

* - possible answers: 1 - very poor, 2 - poor, 3 - average, 4 - good, 5 - very good.

Table 2. Average test scores of psychological domains on Questionnaire for psychological screening $(N=159)$.

\begin{tabular}{lcccc}
\hline Variable & Mean $\pm S D$ & Median & Min - Max $\begin{array}{c}N \text { of patients above } \\
\text { cut-off points (\%) }\end{array}$ \\
\hline Depressive symptoms & $0.34 \pm 0.36$ & 0.22 & $0.00-2.22$ & $2(1.3)$ \\
Diabetes Distress & $2.29 \pm 1.08$ & 2.00 & $1.00-6.00$ & $52(32.7)$ \\
Fear of Hypoglycemia & $0.87 \pm 0.74$ & 0.66 & $0.00-4.00$ & $14(8.8)$ \\
Family support* & $0.88 \pm 0.79$ & 0.66 & $0.00-3.67$ & $37(23)$ \\
\hline
\end{tabular}

\footnotetext{
*- Higher score means less family support.
} 


\subsection{Associations Between Psychological Variables, Age, Glycemic Control and BGM}

The correlation (Spearman's rhos) between psychological variables, age, glycemic control and BGM is presented in Table 3. There were statistically significant associations between all psychological variables, among which the strongest associations were displayed between diabetes distress, depressive symptoms and lack of family support.
Good glycemic control was associated with lower diabetes distress, better family support and more frequent BGM $(r=-0.22, p=0.009)$.

Moreover, older patients reported less depressive symptoms, had better glycemic control $(r=-0.20, p=0.013)$ and more BGM $(r=-0.24, p=0.003)$.

Table 3. Associations between psychological variables, age, glycemic control and BGM $(N=159)$.

\begin{tabular}{lcccc}
\hline Variable & $\begin{array}{c}\text { Depressive } \\
\text { symptoms }\end{array}$ & $\begin{array}{c}\text { Diabetes } \\
\text { Distress }\end{array}$ & $\begin{array}{c}\text { Fear of } \\
\text { Hypoglycemia }\end{array}$ & $\begin{array}{c}\text { Family } \\
\text { support* }\end{array}$ \\
\hline $\begin{array}{l}\text { Depressive symptoms } \\
\text { Diabetes Distress }\end{array}$ & & $0.50(<0.001)$ & $0.30(<0.001)$ & $0.36(<0.001)$ \\
Fear of Hypoglycemia & & & $0.22(0.006)$ & $0.56(<0.001)$ \\
& & & & \\
Glycemic control (HbA1c) & $0.12(0.13)$ & $0.37(0.003)$ & $0.32(<0.001)$ \\
BGM (measures per day) & $0.04(0.68)$ & $-0.14(0.09)$ & $0.04(0.60)$ & $-0.07(0.39)$ \\
Age & & & $-0.06(0.49)$ & $-0.15(0.056)$ \\
Age of diabetes onset & $-0.21(0.009)$ & $-0.04(0.65)$ & $-0.13)$ & $-0.11(0.16)$
\end{tabular}

Table presents Spearman's rho, level of statistical significance is written in parentheses.

* - Higher score means less family support.

\subsection{Characteristics of Patients at Risk for Diabetes Distress}

Almost one third of patients scored over the cut-off point on diabetes distress questions. The ones over the threshold were significantly more depressed $(M-W=4252$, $p<0.001)$, reported more worries about hypoglycemia $(M-W=3292, p=0.034)$, had poorer family support $(M-W=4334, p<0.001)$ and poorer glycemic control $(T$-test $=5.276, p<0.001)$. Patients did not differ in age or in BGM according to diabetes distress.
The model of multivariate regression analysis was built to define the strongest predictors. The model was statistically significant $\left(R^{2}=0.49, p<0.001\right.$, Table 4). Power of the model $(1-B)$ was $>0.999$. The strongest predictors of higher diabetes distress, all being statistically significant, were lack of family support, more depressive symptoms, poorer glycemic control, older age and female sex (Table 4).

Table 4. Predictors of higher risk for diabetes distress assessed with DD2 $(N=156)$.

\begin{tabular}{|c|c|c|c|c|c|c|c|}
\hline Predictor & B & $S E$ & Beta $(\beta)$ & $p$ & $R$ & $R^{2}$ & $p$ \\
\hline (Constant) & -1.95 & 0.83 & & 0.021 & 0.70 & 0.49 & $<0.001$ \\
\hline Depressive symptoms & 0.10 & 0.02 & 0.30 & $<0.001$ & & & \\
\hline Fear of Hypoglycemia & 0.11 & 0.09 & 0.08 & 0.243 & & & \\
\hline Family support* & 0.43 & 0.10 & 0.31 & $<0.001$ & & & \\
\hline Glycemic control (HbA1c) & 0.22 & 0.07 & 0.22 & 0.002 & & & \\
\hline BGM (measures per day) & -0.02 & 0.04 & -0.04 & 0.601 & & & \\
\hline Age & 0.07 & 0.02 & 0.21 & 0.002 & & & \\
\hline Sex & 0.44 & 0.15 & 0.21 & 0.003 & & & \\
\hline
\end{tabular}

Multiple linear regression analysis. $B$ is regression coefficient, $S E$ is standard error of coefficient, $\beta$ is standardized regression coefficient, $R$ is multiple correlation coefficient, $R^{2}$ is proportion of variation in dependent variable explained by regression model, $p$ is level of statistical significance.

* - Higher score means less family support. 


\subsection{Sex Differences}

Girls had significantly higher scores of depressive symptoms $(M-W=4426, p<0.001)$ and diabetes distress $(M-W=4304.5, p<0.001)$ than boys, but there were no differences in the FoH or family support. Girls had also higher HbA1c (8.28 vs. 7.84, $T$-test $=-2.708, p=0.008)$.

\subsection{Outcomes of Screening}

All patients received a short report written by a psychologist. Sixty-one (38.1\%) patients should have been invited to call or write and schedule the appointment with a psychologist. As six (3.8\%) patients were already attending psychological treatment, the invitation was sent to 55 patients. In the year after the invitation, six of those patients $(3.8 \%)$ started to visit a psychologist.

Based on the screening, ten $(6.3 \%)$ patients should have received the report with date and hour of session with a psychologist. Since two patients were already included in a psychological treatment, it was sent to eight patients. Of those eight patients, three $(1.9 \%)$ patients attended the appointment with the psychologist.

From the remaining group of patients that were not at risk for emotional problems, according to psychological screening (88 patients, $55.3 \%$ ), only one patient was already included in psychological treatment and no one additionally joined.

\section{DISCUSSION}

Youth and young adults with diabetes are at high risk for the development of depressive symptoms and experiencing diabetes specific distress, which results in a poorer glycemic control. Systematic screening is therefore recommended, although it is rarely formally conducted. Psychological outpatient screening was implemented in Slovene national diabetes center to provide help for the youth and young adults at the greatest risk.

One-year results showed that $1.3 \%$ of the patients screened positively on elevated depressive symptoms. The percentage of patients with elevated depressive symptoms in the present sample was relatively small, compared to the findings of the previous studies (8-11, $16)$, therefore there is a great chance of falsely negative results and the patients that were not detected. Low detection rate can be due to social desirability bias or to the threshold that was set according to $T$-scores $(\geq 65)$ in a general population, and could be set too high. Low detection rate at patients with diabetes on general depression questionnaires has been observed before, therefore the use of different cutoff thresholds was recommended when screening for depression in patients with somatic diseases (39). On the other hand, many screening tools for depression demonstrated low positive predictive values at patients with diabetes, meaning high rates of false positive results (40).

One third of patients reported symptoms considered as significant diabetes distress. The results are in accordance with the previous studies in adult patients with diabetes (39). The burden of the disease combined with general characteristics of adolescence are likely to contribute to this observation. The high frequency of observed diabetes distress puts in question the usefulness of screening and presenting these results to the patients and carers. Presenting results about elevated diabetes distress to the patients could enhance anxiety, whilst inappropriate referrals to a psychologist can have negative effects on the clinical practice. The use of more specific measures with a higher threshold may be of value for screening for the diabetes distress. Perhaps it would be useful to use the HbA1c level as the first screening tool to capture the patients with the worse glycemic control as recommended by Butwicka et al. (32), or to implement prevention programs for lowering diabetes distress for all the patients.

Although it is important to note that the screening tools are not intended for the assessment of the severity of symptoms, the presented results displayed a statistically significant associations between all psychological variables. Patients with diabetes distress were significantly more depressed, reported more worries about hypoglycemia, had less family support, and their glycemic control was less satisfactory. The strongest predictors of higher diabetes distress were lack of family support, more depressive symptoms, poorer glycemic control, older age and female sex. These findings support the results of the previous studies, which demonstrated associations between diabetes-specific distress, and depressive, glycemic control and family factors (2, 9, 2529).

In accordance with the previous studies are also the findings that girls had significantly higher scores of depressive symptoms, diabetes distress and poorer glycemic control $(2,4,9)$. Interestingly, of the eight patients that expressed the need for psychological treatment, seven were girls.

The need for psychological support was expressed by eight $(5.0 \%)$ patients, for whom psychological sessions were scheduled. Fifty-five (34.6\%) patients received an invitation to schedule an appointment with the psychologist by themselves. Altogether, nine patients joined psychological treatment after the psychological screening had been performed. Of the two patients that were positively screened on elevated depressive symptoms, one was already receiving treatment, while the other one did not reply to the invitation. Confirming the diagnosis of clinical depression was therefore not feasible. Other 
ways of inviting patients at risk need to be considered (a telephone call or referral by his/her diabetologist), due to the low response rate to the referrals. Another study in adult diabetic population encountered similar responses from positively screened patients that were not interested in further diagnostic procedure or referrals to specialists, which raises the question of cost-effectiveness for such screening procedures (41).

Before we conclude, the limitations of the present study should be discussed. Firstly, the patients recruited in the study had a wide age range, especially when considering that TSCC scale for depression was designed and valuated for children and adolescents from ten to 18 years. Secondly, TSCC was not intentionally designed as a screening tool, and it was selected because of its availability in the Slovene language and normative data for Slovene population. Thirdly, items for measuring the FoH and family support were designed for the purposes of the screening based on the existing theory and clinical experiences, and were not otherwise tested.

According to our results, the following recommendations were designed. Firstly, there is an urgent need for adapting the screening tool for depression in Slovene language, with a wider age-range and with appropriate psychometric characteristics. WHO-5 or CES-D are two self-reported measures, both brief, with empirically supported cut-of scores to identify youth and young adults at risk for depression (42-45). Secondly, when screening for diabetes distress, a shorter version of Problem Areas in Diabetes Scale PAID-5 instead of DDS2 should be considered, since PAID- 5 showed satisfactory sensitivity and specificity, and the correlation with PAID-20 was high $(r=0.92)(46)$. Thirdly, a previous study using selfreport questionnaires on Slovene adolescents with T1DM showed that 35\% ever experienced suicidal thoughts and almost $9 \%$ attempted suicide (47). Therefore, suicidal ideation should be considered for screening, and possible interventions offered for those who score positively.

\section{CONCLUSION}

In conclusion, the results after one year of psychological screening in the young diabetes population in Slovenia, displayed low depressive symptoms and high diabetes distress rates. The patients with positive screening were invited or referred to individual psychological assessments for further diagnostic procedures or therapy, but only a small percentage of patients responded. Annual assessments of patients' psychological difficulties and referrals to a psychologist or another specialist may be of value for the young diabetes population, although specific screening tools for children and their parents need to be continuously improved or developed.
The value of the presented results for the future clinical diabetes care could be evaluated with prospective studies assessing whether patients with psychological distress would benefit from screening and referrals to psychological treatment. Whether a routine assessment of depression and diabetes distress in pediatric population with diabetes, followed by psychological treatment improves the patient's wellbeing and glycemic control, remains to be determined.

\section{ACKNOWLEDGMENTS}

The authors would like to thank all patients who participated in the study, as well as the diabetes team members of the Department of Pediatric Endocrinology, Diabetes and Metabolism, University Children's Hospital, University Medical Centre Ljubljana.

\section{CONFLICTS OF INTEREST}

The authors declare that no conflicts of interest exist.

\section{FUNDING}

The present study is supported in part by the Slovene National Research Agency (grant number P3-0343).

\section{ETHICAL APPROVAL}

Received from the Slovene National Medical Ethics Committee (Approval No. 76/03/13).

\section{LEGENDS}

T1DM - Type 1 diabetes; BGM - blood glucose monitoring; $\mathrm{HbA1C}$ - glycosylated hemoglobin; FoH - fear of hypoglycemia; ADA - American Association for Diabetes; ISPAD - International Society of Pediatric and Adolescent Diabetes; CDI - Children Depression Inventory; TSCC - Trauma Symptom Checklist for Children; DDS2 - The Diabetes Distress Screening Scale. 


\section{REFERENCES}

1. Kovacs M, Goldston D, Obrosky DS, Bonar LK. Psychiatric disorders in youths with IDDM: rates and risk factors. Diabetes Care 1997; 20: 36-44.

2. Weissberg-Benchell J, Antisdel-Lomaglio J. Diabetes-specific emotional distress among adolescents: feasibility, reliability, and validity of the problem areas in diabetes-teen version. Pediatr Diabetes 2011; 12: 341-4.

3. Steinberg L. A social neuroscience perspective on adolescent risktaking. Dev Rev 2008; 28: 78-106.

4. Dovc K, Telic SS, Lusa L, Bratanic N, Zerjav-Tansek M, Kotnik P. et al. Improved metabolic control in pediatric patients with type 1 diabetes: a nationwide prospective 12-year time trends analysis. Diabetes Technol Ther 2014; 16: 33-40.

5. Helgeson VS, Snyder PR, Seltman H, Escobar O, Becker D, Siminerio L. Brief report: trajectories of glycemic control over early to middle adolescence. J Pediatr Psychol 2010; 35: 1161-7.

6. King PS, Berg CA, Butner J, Drew LM, Foster C, Donaldson D. et al. Longitudinal trajectories of metabolic control across adolescence: associations with parental involvement, adolescents' psychosocial maturity, and health care utilization. J Adolesc Health 2012; 50: 491-6.

7. Drotar D, Ittenbach R, Rohan JM, Gupta R, Pendley JS, Delamater A. Diabetes management and glycemic control in youth with type 1 diabetes: test of a predictive model. J Behav Med 2013; 36: 234-45.

8. Lawrence JM, Standiford DA, Loots B, Klingensmith GJ, Williams $\mathrm{DE}$, Ruggiero $\mathrm{A}$. et al. Prevalence and correlates of depressed mood among youth with diabetes: the SEARCH for diabetes in youth study. Pediatrics 2006; 117: 1348-58.

9. Hood KK, Huestis S, Maher A, Butler D, Volkening L, Laffel LM. Depressive symptoms in children and adolescents with type 1 diabetes: association with diabetes-specific characteristics. Diabetes Care 2006; 29: 1389-91.

10. Whittemore R, Urban AD, Tamborlane WV, Grey M. Quality of life in school-aged children with type 1 diabetes on intensive treatment and their parents. Diabetes Educ 2003; 29: 847-54.

11. Naar-King S, Idalski A, Ellis D, Frey M, Templin T, Cunningham PB. et al. Gender differences in adherence and metabolic control in urban youth with poorly controlled type 1 diabetes: the mediating role of mental health symptoms. J Pediatr Psychol 2006; 31: 793-802.

12. Moussa MA, Alsaeid M, Abdella N, Refai TM, Al-Sheikh N, Gomez JE. Social and psychological characteristics of Kuwaiti children and adolescents with type 1 diabetes. Soc Sci Med 2005; 60: 1835-44.

13. Johnson B, Eiser C, Young V, Brierley S, Heller S. Prevalence of depression among young people with Type 1 diabetes: a systematic review. Diabet Med 2013; 30: 199-208.

14. Ciechanowski PS, Katon WJ, Russo JE. Depression and diabetes: impact of depressive symptoms on adherence, function, and costs. Arch Intern Med 2000; 160: 3278-85.

15. McGrady ME, Laffel L, Drotar D, Repaske D, Hood KK. Depressive symptoms and glycemic control in adolescents with type 1 diabetes: mediational role of blood glucose monitoring. Diabetes Care 2009; 32: 804-6.

16. Corathers SD, Kichler J, Jones NH, Houchen A, Jolly M, Morwessel $\mathrm{N}$. et al. Improving depression screening for adolescents with type 1 diabetes. Pediatrics 2013; 132: 1395-402.

17. Hilliard ME, Herzer M, Dolan LM, Hood KK. Psychological screening in adolescents with type 1 diabetes predicts outcomes one year later. Diabetes Res Clin Pract 2011; 94: 39-44.

18. Gonder-Frederick LA, Fisher CD, Ritterband LM, Cox DJ, Hou L, DasGupta AA. et al. Predictors of fear of hypoglycemia in adolescents with type 1 diabetes and their parents. Pediatr Diabetes 2006; 7: $215-22$.
19. Gonder-Frederick L, Nyer M, Shepard JA, Vajda K, Clarke W. Assessing fear of hypoglycemia in children with Type 1 diabetes and their parents. Diabetes Manag 2011; 1: 627-39.

20. Wild D, von Maltzahn R, Brohan E, Christensen T, Clauson P, Gonder-Frederick L. A critical review of the literature on fear of hypoglycemia in diabetes: Implications for diabetes management and patient education. Patient Educ Couns 2007; 68: 10-5.

21. Cox DJ, Gonder-Frederick L, Antoun B, Clarke W, Cryer P. Psychobehavioral metabolic parameters of severe hypoglycemic episodes. Diabetes Care 1990;13: 458-9.

22. Shiu AT, Wong RY. Fear of hypoglycaemia among insulin-treated Hong Kong Chinese patients: implications for diabetes patient education. Patient Educ Couns 2000; 41: 251-61.

23. La Greca AM, Auslander WF, Greco P, Spetter D, Fisher EB, Jr., Santiago JV. I get by with a little help from my family and friends: adolescents' support for diabetes care. J Pediatr Psychol 1995; 20: 449-76.

24. Anderson B, Ho J, Brackett J, Finkelstein D, Laffel L. Parental involvement in diabetes management tasks: relationships to blood glucose monitoring adherence and metabolic control in young adolescents with insulin-dependent diabetes mellitus. J Pediatr 1997; 130: 257-65.

25. Helgeson VS, Reynolds KA, Siminerio L, Escobar O, Becker D. Parent and adolescent distribution of responsibility for diabetes self-care: links to health outcomes. J Pediatr Psychol 2008; 33: 497-508.

26. Cameron FJ, Skinner TC, de Beaufort CE, Hoey H, Swift PG, Aanstoot $\mathrm{H}$. et al. Are family factors universally related to metabolic outcomes in adolescents with Type 1 diabetes? Diabet Med 2008; 25: 463-8.

27. Wysocki T. Associations among teen-parent relationships, metabolic control, and adjustment to diabetes in adolescents. J Pediatr Psychol 1993; 18: 441-52.

28. Miller-Johnson S, Emery RE, Marvin RS, Clarke W, Lovinger R, Martin $M$. Parent-child relationships and the management of insulindependent diabetes mellitus. J Consul Clin Psychol 1994; 62: 603-10.

29. Miller VA, Drotar D. Decision-making competence and adherence to treatment in adolescents with diabetes. J Pediatr Psychol 2007; 32: 178-88.

30. Silverstein J, Klingensmith G, Copeland K, Plotnick L, Kaufman F, Laffel L. et al. Care of children and adolescents with type 1 diabetes: a statement of the American Diabetes Association. Diabetes Care 2005; 28: 186-212.

31. Delamater AM. Psychological care of children and adolescents with diabetes. Pediatr Diabetes 2009; 10: 175-84.

32. Butwicka A, Fendler W, Zalepa A, Szadkowska A, Mianowska B, Gmitrowicz A. et al. Efficacy of metabolic and psychological screening for mood disorders among children with type 1 diabetes. Diabetes Care 2012; 35: 2133-9.

33. Briere J, Žemva B, Boben D. Vprašalnik o travmatiziranosti otrok in mladostnikov: priročnik. Ljubljana: Center za psihodiagnostična sredstva, 2000.

34. Evans JJ, Briere J, Boggiano AK, Barrett $M$. Reliability and validity of the Trauma Symptom Checklist for Children in a normal sample. In: San Diego Conference on Responding to Child Maltreatment. San Diego, 1994.

35. Sadowski CM, Friedrich WN. Psychometric properties of the Trauma Symptom Checklist for Children (TSCC) with psychiatrically hospitalized adolescents. Child Maltreat 2000; 5: 364-72.

36. Fisher L, Glasgow RE, Mullan JT, Skaff MM, Polonsky WH. Development of a brief diabetes distress screening instrument. Ann Fam Med 2008; 6: 246-52.

37. PASW $®$ Statistics 18.0 .0 Somers, New York: SPSS, An IBM Company, 2009.

38. Faul F, Erdfelder E, Buchner A, Lang AG. Statistical power analyses using $G^{*}$ Power 3.1: tests for correlation and regression analyses. Behav Res Methods 2009; 41: 1149-60. 
39. Hermanns N, Kulzer B, Krichbaum M, Kubiak T, Haak T. How to screen for depression and emotional problems in patients with diabetes: comparison of screening characteristics of depression questionnaires, measurement of diabetes-specific emotional problems and standard clinical assessment. Diabetologia 2006; 49: 469-77.

40. Roy T, Lloyd CE, Pouwer F, Holt RI, Sartorius N. Screening tools used for measuring depression among people with Type 1 and Type 2 diabetes: a systematic review. Diabet Med 2012; 29: 164-75.

41. Fleer J, Tovote KA, Keers JC, Links TP, Sanderman R, Coyne JC. et al. Screening for depression and diabetes-related distress in a diabetes outpatient clinic. Diabet Med 2013; 30: 88-94.

42. Bech P, Olsen LR, Kjoller M, Rasmussen NK. Measuring well-being rather than the absence of distress symptoms: a comparison of the SF-36 Mental Health Subscale and the WHO-Five Well-Being Scale. Int J Methods Psychiatr Res 2003; 12: 85-91.

43. de Wit M, Pouwer F, Gemke RJ, Delemarre-van de Waal HA, Snoek FJ. Validation of the WHO-5 Well-Being Index in adolescents with type 1 diabetes. Diabetes Care 2007; 30: 2003-6.
44. Roberts R, Andrews J, Lewinsohn P, Hops H. Assessment of depression in adolescents using the Center for Epidemiologic Studies Depression Scale. Psychol Assess 1990; 2: 122-8.

45. Roberts RE, Lewinsohn PM, Seeley JR. Screening for adolescent depression: a comparison of depression scales. J Am Acad Child Adolesc Psychiatry 1991; 30: 58-66.

46. McGuire BE, Morrison TG, Hermanns N, Skovlund S, Eldrup E, Gagliardino J. et al. Short-form measures of diabetes-related emotional distress: the Problem Areas in Diabetes Scale (PAID)-5 and PAID-1. Diabetologia 2010; 53: 66-9.

47. Radobuljac MD, Bratina NU, Battelino T, Tomori M. Lifetime prevalence of suicidal and self-injurious behaviors in a representative cohort of Slovenian adolescents with type 1 diabetes. Pediatr Diabetes 2009; 10: 424-31. 